This is an Accepted Manuscript of an article published by Taylor \& Francis in Gender and Education on 8/10/2012, available online: http://www.tandfonline.com/doi/pdf/10.1080/09540253.2012.740448

The article published as:

Ames, Particia (2013) "Constructing new identities? The role of gender and education in rural girls' life aspirations in Peru", Gender and Education 25 (3): 267-283. DOI:

$10.1080 / 09540253.2012 .740448$

The article is reproduced in according with the self-archiving policies of Taylor \& Francis. 


\title{
Constructing new identities? The role of gender and education in rural girls' life aspirations in Peru
}

\author{
Patricia Ames* \\ Instituto de Estudios Peruanos, Lima, Peru
}

\begin{abstract}
This paper focuses on rural and indigenous girls and their mothers in Peru, examining how they position schooling and education in their current life and future aspirations, in order to better understand girls' increasing participation in education. It is argued here that the high educational aspirations girls and their families have are not only related to the desire to overcome poverty and marginalisation but also to oppressive gender relations. The widening of female roles available to young rural women is impacting on their identities and life projects. The paper shows that these processes are not purely individual but intertwined with intergenerational agreements, family projects, and shared understandings of the changes needed to improve the life of young women, revealing important transformations in rural and indigenous families. The paper analyses qualitative data from boys and girls in three settings and focuses in more detail on three in-depth case studies.
\end{abstract}

Keywords: indigenous girls, rural girls, educational aspirations, Peru, gender identities

\footnotetext{
*Corresponding autor: pames@iep.org.pe
} 


\section{Introduction}

Girls and women in developing countries are participating in school systems more than ever in history and this has already produced significant social and cultural changes. However the pace of change may be different for different groups of women. Thus for example, in Peru, a South American country with almost universal enrolment and gender parity in basic education, research indicates that inequalities affect mainly poor, rural and indigenous women (Montero 2006). Nevertheless, younger generations of rural women are advancing more in their education and show high educational aspirations.

This paper focuses on rural and indigenous girls and examines how these girls, and their mothers, position schooling and education in their current life and future aspirations, in order to understand better the process through which girls are increasingly participating in education. It is argued here that the high educational aspirations girls and their families have are not only related to the desire to overcome poverty and marginalisation but also to oppressive gender relations. The widening of female roles available to young rural women impacts the formation of their identities and life projects. The paper shows that this process is not purely individual but intertwined with intergenerational agreements, family projects, and shared understandings of the changes needed to improve the lives of young women, revealing significant transformations within rural and indigenous households. The paper draws on data from Young Lives, a longitudinal study of childhood poverty in four developing countries including Peru. The study combines quantitative and qualitative methods of data collection, including in-depth case studies of selected children. This paper focuses on qualitative case studies from three different communities and ethnic groups. Case studies of three girls are presented in more detail. They were selected for their 
relevance to understanding the changes in educational aspirations and current trends in school enrolment.

\section{The Peruvian context: unequal improvements in women's lives}

The situation of Peruvian women has changed rapidly in the last five decades, as in the rest of Latin America, with the modernisation process and access to the educational and health systems and labour market, as well as opportunities for political participation. However, these rapid changes are by no means simple: some gains are fragile, others face resistance and there are plenty of contradictions, such as the coexistence of deep transformations in social relations with traditional gender roles in the domestic sphere. Gender violence, for example, is still highly prevalent: in $2009,39 \%$ of women reported physical violence by their male partners (INEI 2010a). More importantly, the pace of change in women's life is not the same across different groups of women, affected differently by their class, ethnicity and location. Thus, on the one hand several indicators show positive changes towards more equal gender relations in political, economic and social life: women can now access positions of political representation with the support of Peruvian law, which requires a quota of $30 \%$ of women in each list for local, regional and national elections. Women's participation in the National Congress increased to $29 \%$ in 2006, although this figure dropped to 20.76 in the last national elections in 2011. Growth in women's participation in education is also notable: in the 1981 National Census only $8.5 \%$ of Peruvian women accessed higher education, while in the 2007 National Census 30\% were enrolled. Similarly, the number of women without education went down from $23 \%$ to $11 \%$ in the same period, although this rate is almost three times more than for men (4\%). Nevertheless, current basic education enrolment rates show gender parity. Likewise, women's participation in economic life has increased to account for $45 \%$ of the Economically Active 
Population in 2009. However, women receive only $60 \%$ to $80 \%$ of what men are paid for the same job (MINTRA 2009).

On the other hand, however, these changes do not apply to all women: in 2009 while urban women had in average of 8.4 years of schooling, rural ones only had 4.4 years (MINTRA 2009). Similarly, while only $6 \%$ of women whose mother tongue is Spanish have no schooling at all, according to the 2007 National Census, among indigenous Quechua women this proportion is $31 \%$. The considerable economic growth in Peru also affects urban and rural areas differently: although the economy grew by $9 \%$ in 2009 and the poverty rate fell from 48.6 in 2004 to $34.8 \%$ in 2009 , poverty continues to be more concentrated in rural areas, where $60 \%$ of people are poor, almost three times the rate in urban areas (21\%) (INEI 2010b). Rural women therefore are more affected by poverty than their urban peers.

Despite the persistent inequalities affecting rural women, younger generations have been increasing their participation in education in the last decade: according to the National Household Survey of 2010, rural women aged between 14 and 25 years old have an average of eight years of education, two years more than women aged between 26 and 35 years old and considerably more than older age groups; moreover, within the younger group (14-25) there is no gender gap: girls and boys are achieving the same number of years of schooling. ${ }^{1}$

This paper examines the educational aspirations of rural and indigenous girls and women, which are linked with these recent statistical trends. These two groups (rural girls and indigenous girls) overlap to some extent but are not exactly the same: most indigenous people live in rural areas, although there is a growing proportion living in urban centres. There are also girls living in rural areas who are not indigenous but whose families share 
similar livelihoods and disadvantages. This paper considers both rural girls and indigenous girls.

\section{Methods, research participants and settings}

This paper is primarily based on data gathered as part of Young Lives, a study investigating the changing nature of childhood poverty in Ethiopia, India (in the state of Andhra Pradesh), Peru and Vietnam over 15 years. Young Lives periodically collects survey information from 3,000 children of two age cohorts and, in Peru, it tracks 50 of these children in order to compile qualitative, in-depth case studies. The case study children were randomly selected from the main sample in a limited number of sites in 2007 and the same children are visited over the years.

The qualitative methodology includes individual interviews with children and adults and group-based activities with children and semi-participant observations of children's homes, schools and communities, in order to build up a comprehensive picture of children's immediate social contexts.

In this paper I focus mainly on girls from the Older Cohort (born 1994-95), who were 1213 years old during the first set of qualitative research interviews (2007). Data from sameage boys from the same communities is also used to frame and complement the analysis. A second set of interviews and group activities was conducted one year later (in 2008) and the Round 3 survey took place in 2009. Further rounds of survey and case study data collection are planned through to 2015. The data on girls include interviews with their mothers. The support of the mother could be fundamental to ensuring the continuity of the girl's desired educational trajectory (Meyers 2011). For this reason, I pay attention to both girls and their mothers, with the aim of understanding how education features in girls' aspirations, what 
kind of support they get at home and how such aspirations impact the construction of their female identities.

Although Young Lives gathers information across 20 sites in Peru, for this paper I focus on three different settings where case studies were conducted: 'Andahuaylas', a Quechua rural village in the Andes; 'Rioja', a coffee-growing (rural) village in the Amazon; and 'Juliaca', an Andean city characterised by the presence of Quechua and Aymara people coming from the surrounding rural areas. ${ }^{2}$

\section{Empirical and theoretical background}

Ten years before carrying out my first interviews with rural and indigenous girls participating in the Young Lives study, in 1997, I was involved in a study on the educational exclusion of rural (and indigenous) girls in four different communities in the Andes. Findings showed that several significant factors were behind the low educational attainment (below complete primary education) of Andean rural women. The relationship between indigenous and rural girls and schools was very fragile: temporary or permanent drop-out was common in order to help with farming and domestic work, especially among poorer households. Parents showed a preference for boys' education. Schools were poorly resourced and culturally and linguistically alien to the girls. Teachers had low educational expectations for rural girls and used old-fashioned and ineffective pedagogies; physical punishment was commonly used, as well as gendered practices that reinforced traditional female roles. As much as this type of school experience pushed girls out, girls also chose actively to resist stereotypes about themselves by withdrawing. Indeed, several girls who had dropped out found more satisfaction in participating in household activities, learning useful things to become valued women in their own culture and contributing to the family 
economy. All this contrasted sharply with what school had to offer them, which was indeed less attractive from their point of view (Oliart 2004, Ames 2005).

The situation described above is not unique to the Peruvian context: scholarly work in different countries in Latin America has shown that rural and indigenous girls face more educational disadvantages than urban girls and their male peers: they tend to leave school earlier than boys and complete fewer years of education; as a result the gender gap in favour of males persists among such groups, in contrast with the rest of the population (Stromquist 2006; Winkler 2004; UNESCO 2002).

Nevertheless, and in contrast with my previous work, in 2007, when I started the interviews with Young Lives girls, all of them were in the last year of primary school or the first three years of secondary school. And, more significantly, all of them were clearly determined to complete secondary schooling, a goal supported by their mothers. If other factors such as poverty, ill health and low school quality continued to menace rural girls' education, there was one important thing that had changed in significant ways: the attitude towards girls' education, among their families, but also among girls themselves.

Feminist research has already established that conventions about female roles, like those regarding gender relations, change through time. Connell and Messerschmidt (2005, 848) state that gender hierarchies are also impacted by new configurations of women's identity and practice, especially among younger women. The massive expansion of schooling in Latin American rural areas has certainly contributed to this. . My argument here is that young rural women are embracing education as part of a broader process of widening the range of subject positions that had previously been available to them. Indeed, as Leahy (1994) indicates, social agents may choose from a variety of subject positions, take one up or even create a new one, thus provoking social changes. These changes are in turn affected 
by and affect social identities, conceptualised here as multiple, shifting and evolving, affected by structural constraints but also negotiated within specific social situations (Holland et al. 1998; Luykx 1996).

Current interest in the construction and transformation of women's identities suggests that far from being superficial, the change of attitudes emerging among rural girls in this study may reflect turning points in the ongoing construction of their very identities. Indeed, the 'educational desire' of young women from marginalised groups, has been one major driving force for change and transformation in women's lives, as Mirza (2006) reminds us, and a way to contest and challenge the stereotypes about them. Although much scholarly work has shown how schools have acted to reproduce gender ideologies and hierarchies, it has also shown how girls and women resist, reject, but also appropriate school credentials to change their subordinate status (Lutrell 1996). Indeed, the expansion of schooling in rural areas of Peru in recent decades, with discourses of modernisation and 'progress', has been a powerful force in shaping new and different expectations for young rural people (Ames 2002).

In what follows I will introduce rural and indigenous girls' and boys' educational aspirations. I then highlight how, despite girls and boys showing very similar aspirations, there is an additional meaning for girls' educational desire, related to the unequal gender relations surrounding them. Three case studies are examined to illustrate this point through the analysis of the girls' and their mothers' perspectives. Another section presents the discussion and afterwards the final section the conclusions.

\section{Narratives of progress: schooling as a way out of poverty}

The 670 children of the Older Cohort participating in the Young Lives study in Peru have shown high rates of enrolment in education across the three survey rounds $(2002,2006$, 
2009), with no significant gender gaps. However the enrolment rate has fallen from $98 \%$ in Rounds 1 and 2 to $91 \%$ in Round 3, when children were 14-15 years old and should have been nearing the end of secondary school. This average was lower for rural areas, at $86 \%$, but still high for a developing country context (Cueto et al. 2011). The high levels of enrolment in education, even in poor rural areas, are related to high educational aspirations from both children and their parents. Crivello (2009), examining children's responses on their desired educational attainment during the Round 2, found that $90 \%$ wanted to complete higher education - either university $(78 \%)$ or technical college $(12 \%)$. Caregivers' aspirations were similar: $92 \%$ of them wanted higher education for their children - either university $(75 \%)$ or technical school (17\%).

The qualitative case studies showed similar results: All 21 case study children from the three sites featured in this paper, both boys and girls, valued highly education. They constantly highlighted a link between education and their present and future well-being, understood in broad terms: in the participatory group sessions devoted to the 'Well-being exercise' - in which children were asked to imagine and draw a child who is doing well in life and a child who is not doing well - in all cases the child that was doing well went to school. When explaining and discussing their drawings, all children stated that going to school was a very important indicator of well-being. Consistently, when explaining their images of a child who is not doing well in life, participants depicted children who did badly at school, who did not show interest or put effort into their work; or children that did not go to school and thus had to work hard for a living. To end up with no education or an incomplete education is a clear sign of ill-being (understood here as not doing well in life) because these children will not have a good life and will not have qualifications to support their own family economically, according to the research participants. With their mirror 
images of well-being and ill-being, children showed they were acutely aware of the importance of education for their future, and were very explicit about it. For children, going into higher education and achieving professional qualifications and status, was synonymous with 'becoming somebody in life'.

Education was related to the goal of becoming a professional (profesional in Spanish, referring to occupations such as teaching, medicine, nursing, the law, engineering, etc.), which children (and their parents) associated with the possibility of having a better life, as a way out of poverty.

The importance of education was also confirmed through individual interviews with case study children. Schooling was linked with life course aims, as a means of upward social mobility. Children' desired educational trajectories show many similarities between boys and girls (see Tables A.1 and A.2 in the Appendix). Thus, it is noticeable that, when they were at the start of secondary school, all children wanted to complete secondary education and pursue higher education and a variety of 'professions' as explained above.

Parents also stressed the importance of education for their children to be 'more', and to 'escape' agricultural work and poverty in general, and expressed high educational aspirations for both boys and girls.

Most of the children in the study had succeeded in progressing to the last year of secondary school or completing it by the last time they were visited (2011). Interestingly, there were more boys (3) than girls (1) who had dropped out before completing secondary school. All of the boys who dropped out were over-age (a year or two behind the expected grade for their age), worked as agricultural workers while at school and finally left school to migrate for work and contribute to the household economy. The only girl who dropped out left the area with her boyfriend. This contrast may show that pressing economic needs may impact 
more on boys, whose paid labour in agriculture may be required earlier, while the early formation of couples may impact more on girls.

Both parents and children considered educational achievements and better-paid jobs as goals not only in individual terms, but also for their implications for the whole family: help with the school expenses of younger siblings and financial support for parents when old were mentioned by most, but more explicitly expressed by the indigenous girls in Andahuaylas.

While school education is recognised as important for both boys and girls to escape poverty, it is becoming even more important for girls and their mothers, who, in addition, see access to higher levels of education as a way out of oppressive gender relations and economic dependence on men. This attitude represents a major shift within rural and indigenous households. In what follows I present three case studies that best illustrate these attitudes, one from each of the three different contexts studied.

\section{Eva: education and marginalisation}

Eva was the second of four siblings and lived with them and both parents in a Quechua rural community in the southern Andes. The Quechua are the main indigenous group in Peru: the 2007 National Census reported 3,261,750 Quechua speakers, representing 83\% of the indigenous population.

At 12 years old, Eva went from her rural primary school to a public secondary school in the district capital. There, she was marginalised for being indigenous and rural: she told us that her classmates called her names and said that she did not have any friends at school but played with a cousin during breaks. She commuted every morning to attend school. It takes about 30 minutes by car but sometimes, on her way back, she has to walk. However, Eva continued attending that school instead of the local one in her village, as the town schools 
are perceived to be of better quality. She showed no signs of regret for her choice but a clear idea of what she is looking for:

Interviewer: Do you miss your primary school?

Eva: No... because I want to finish quickly my secondary school ... to be professional. When her father got sick, in 2008, her family faced further economic constraints, but Eva made additional efforts to continue attending the school in town: '[When my father got sick] there was no money for our bus ticket ... [thus] my brother and I went to work on Saturdays [referring to paid agricultural work ].' Eva's parents had more schooling than the average in the village: her father had completed secondary school, and her mother had eight years of education. All but one of the other mothers of case study children in this village had no schooling, and all but one of the other fathers had not been educated beyond primary school level. Perhaps because of her own (incomplete) educational experience, Eva's mother was supportive of Eva's schooling, since she envisaged a way out of poverty and suffering through education:

Eva's mother: I want Eva to study, to become professional, [and] to pay attention. Interviewer: Why do you want her to become professional?

Eva's mother: If she is not a professional, what money would she have? She will suffer then. If she works [as a professional] each month she will earn [money].

Eva's mother worked at home and on the family farm and wanted something different for her daughter. Eva's determination to study, against the odds she found at school, was aligned with such wishes. There appears to be strong intergenerational communication and agreement in terms of educational goals in Eva's family, as with others in our sample, situating the importance of education as part not only of individual but also of family projects. 
However, despite being a shared project, schooling may entail some tensions that are difficult to handle. Thus for example, Eva's mother was concerned about how Eva misbehaved with local girls, showing off and trying to act superior, and refused to speak Quechua at home. In the same vein, Eva did not use the traditional shawl local women and girls used in the village any more, but wore modern sports clothes, like the town's young people. Although Eva was aware on the one hand of the discrimination against her for being rural and indigenous, on the other hand she also discriminated against the local girls in her home village, and internalised the discourse of inferiority associated with rurality and ethnicity by refusing to wear traditional clothes and to speak her indigenous language. Thus, although resisting in one way the discourse of inferiority, by pursuing education and 'going ahead', Eva also reproduced it in her relations with girls more attached to their indigenous traditions. Eva's attitude needs to be placed in the context of a school system that historically had offered a national identity and citizenship to indigenous people, but while asking as a price the neglect of their very ethnic identity (Ames 2002), which is marginalised and excluded from the very beginning of primary school, as research with the Younger Cohort of children in this same community has shown (Ames 2011).

\section{Maria: changing ideas about a better life}

Maria attended the local multigrade primary school in a rural village in Rioja (Upper Amazon), where she lived with both her parents and two younger sisters. Her family and neighbours are colonos, Spanish-speaking migrants from a neighbouring Andean region. Maria's village had no secondary school but there were two available nearby: in a neighbouring, bigger rural village and in the district capital, both at a distance of 45 minutes' walk from her home. However, her family decided on a third, different arrangement, using family networks in the region: thus, at the age of 12 , Maria went to live 
with her grandparents in a bigger rural village with a public secondary school, about two hours from her home by public transport. Her parents and sisters visited her regularly, every two weeks, and they were considering a move there once the second daughter (one year younger) had completed primary school. Maria's schooling was therefore not something determined by her individual choices, preferences and possibilities, but inscribed instead in shared aspirations, extended family arrangements and family projects for the medium to long term.

Despite the change of village and school, Maria liked secondary school and seemed to adapt well:

Maria: I like study ... because it is nice $\ldots$ because they teach us to read, to write, to do something in life, to add, to subtract, to divide.

Interviewer: Do you think schooling is going to be useful in the future?

Maria: Yes, if we do a small business, we already know to add, to subtract, to divide.

Maria liked study and considered it important for the future and for work, an attitude supported by her mother. Indeed, like many other parents in our sample, Maria's mother considered that education was the most important thing for Maria's future, since with school qualifications) 'she can have a job'.

Maria's mother took care of her home, worked on her farm and sold beauty products. Maria helped her by doing domestic chores and working on the farm, but Maria's mother had different, higher aspirations for her daughter, such as university studies. She acknowledged however that due to poverty, it might not be possible for her to finance it. Nevertheless she was determined to make her daughters complete at least secondary education, something she herself couldn't do: she only attended up to the first year of secondary school. Thus, she 
encouraged Maria to do well at school: 'I always advise her, "you have to study always", I said to her, in order to pass her exams.' And her daughter was willing to do so.

When discussing how she envisaged Maria's future, she showed a new attitude in her context: instead of identifying a preferred moment for marriage and children, as common (and highly valued) steps in the life course of rural women, Maria's mother considered an alternative possibility:

I don't want anything of that [having a family], no grandchildren, nothing, just my daughter... so she can progress a bit, you know, working, because with family it is almost not possible.

Her response shows a critical stance towards having a family as a mandatory step in the life of women, implying that she does not necessarily see marriage and children as defining a woman's identity and suggesting that she thinks marriage may slow down or stop her daughter's 'progress' in life . Interestingly, Maria did not identify a moment for marriage or children during the conversation about her future and saw herself as studying or working. The idea of alternative positions and activities available to women besides their traditional roles as wives and mothers may be widespread in urban areas, but they are much less so in rural areas, where parenthood is seen as acquiring full status as an adult person, both for men and women. New roles seem more present now, configuring different horizons for younger generations. The next case study shows an even more explicit discourse in this regard. 


\section{Luz: in search of autonomy}

Luz is an Aymara girl who lived in the Andean city of Juliaca. The Aymara are the secondlargest indigenous group in Peru, with 440,380 people according to the 2007 National Census.

The older of two sisters, Luz lived with her parents and her sister, and another family formed by her aunt, her uncle and their son. She attended a prestigious public secondary school in her city. Although Luz was born in the city, her family comes from a rural background-. This background is reflected in a tradition typical of rural areas: the involvement of children in the family's productive and domestic activities. In contrast with Eva and Maria, Luz did not work on the family farm but at her parents' small textile factory, attached to her home. The family business is to produce clothes and sell them in local and regional markets. Luz's mother is in charge of sales, travelling twice per week outside the region. Luz's mother completed secondary school, and her father studied for some years in a technical college, showing again an education slightly above the mean in this site, where most mothers have at least some secondary education, but two showed lower levels (no education or only one year).

Luz liked helping her parents and learning the textile trade, in which she had been involved since she was nine years old. Although she was not paid for her work, she considered this fair, as her parents paid for her education, clothes and food, and thus her work was part of the family economy. Although Luz was proud to know how to operate all the machines in the factory and liked sewing, she wanted to finish secondary education and go to university to pursue a professional career as an accountant or manager. Marriage and children were not necessarily part of her future plans: 
Luz: I don't want to marry, I want to be like my aunt, [who is] single. She is 27 and she is single. My aunt enjoys herself. I want to be like that ... she is professional. My mother also tells me: 'Stay single, don't look for a husband, be professional, look at your aunt who is alone. She enjoys better, nobody stops her, nobody says anything to her.' So I want to be like that, like my aunt, have fun and then marry, at 30 years old. [Laughs]

Luz's role model was a single, professional and young woman: her aunt. It is not an anonymous, idealised model, but someone with whom Luz has a close and affectionate relationship, part of her family, in a culture that strongly values extended family networks: it is noteworthy that Luz lived with relatives, who also worked in the family business; that she frequently met her single aunt, who lives nearby, visited her grandparents in the countryside frequently, and valued family gatherings as the happiest moments in her life. In Luz's vision of her future life as an adult, marriage appears again (as in the case of Maria's mother) as something that may be an obstacle for a woman's advancement or personal progress. The advice of her mother as reported by the girl is clear in that respect and shows awareness of the unequal power relations between men and women, especially married couples, where women still may face oppressive experiences. One of them is gender violence, which, as stated in the introduction, has a high prevalence in Peru. Indeed Luz had witnessed tension and violence between the married couples in her home:

I don't like it when my parents argue. My dad comes home drunk and he gets stubborn, and they argue, and my mom is a bit crazy, she reacts badly. My uncle is also jealous. My aunt is always cheerful, and he gets jealous when she is cheerful. I don't like it. The other day my uncle and my aunt were fighting, and it was ugly, and he hit her. I got scared. My baby cousin was crying $\ldots .$. 
Once, my dad hit my mom. I was scared. Her eye turned purple (...) . My sister and I we were both crying - my aunt was desperate: 'How can you leave her eye like that?' [she said]. My mum was crying. My dad was bad - he had never hit her before.

Gender violence in the life of married women and the control exerted by husbands may be related to Luz's reluctance to put marriage in the centre of her plans, although she did not discard the possibility. Also the attitude of her parents, who supported her plans to work hard and go to university, helped her to put those plans in a more prominent position. Indeed, Luz's parents, who were interviewed together, were emphatic about the importance of education. When asked about marriage, during the discussion of life course events, they stated that it would happen only 'if she wants it, but not if she does not ', showing also that for them marriage is not a central or defining goal for their daughter's future. Thus Luz can choose from several possibilities and trajectories for a young woman beyond the traditional roles of wife and mother: studying, working, enjoying herself. Other women in her life (her mother and her aunt), and also her father, have helped her to be able to recognise and to aspire to such possibilities, showing once again how personal and individual aspirations are also intertwined with family and intergenerational projects, with the construction and reconstruction of female identities.

\section{Discussion}

The three case studies presented above show different but interconnected issues surrounding girls' educational aspirations. Issues of social marginalisation, ethnic discrimination, gender inequality and gender violence appear in the background of otherwise common statements about wanting to study. In this section I discuss these issues and go back to the original research questions: the place of education in girls' aspirations and the home support for that are discussed first, in relation to the role of schools in 
producing educational aspirations. The he impact of both on the construction of girls' female identities - is addressed later.

Schools are well known as places where dominant social norms and expectations are presented, inculcated and enforced, particularly to students from minorities or lower social classes as well as to female ones. But schools are also sites where such norms are rejected, resisted and negotiated among social agents (Holland and Levinson 1996). The legitimation of schooling as a way to upward mobility, individual and collective improvement and its various associations with the desire of 'becoming somebody' (Wexler 1992; Lutrell 1996) has not been straightforward in many contexts.

In Latin America, rural people have both resisted and appropriated schooling, distrusting schools whilst simultaneously fighting to educate their children, expressing with these contradictory actions the different meanings and social goals behind pedagogical and political projects sustaining school expansion in rural areas (Rockwell 1996; Luykx 1996, 1999; Meyers 2011). Peru has not been an exception and the mix of educational desire and distrust has been in place for decades if not centuries (Ames 2002). As in the rest of Latin America, rural and indigenous women have been incorporated into school to a much lesser extent that their male peers, reflecting not only gender inequalities both in the dominant society and in their own cultural groups, but also women's own resistance to the ways schools try to define and stereotype rural and indigenous femininities.

With this background in mind, the results presented in this paper cannot be explained based on plain acceptance and compliance. On the contrary, I believe the emerging picture is a more complex one. Although girls (and their mothers) seem to accept that educational careers are the most desirable project, leaving behind other ways of life (i.e. as peasants and 
indigenous women living of their lands and crafts), they also articulate several critiques to their existing social worlds when choosing this path.

The findings of the study show indeed that education features prominently in girls' aspirations and efforts for changing their lives and their futures. I have argued, based on my previous research and the recent trends highlighted by Peruvian statistics, that this attitude in turn represents a major change in the mindset of younger rural women, since just a decade ago girls of about the same age and context saw little point in going through schooling (Oliart 2004, Ames 2005). Moreover, girls seem to get significant support at home to develop such aspirations. This represents also a change in parental attitudes, as previous studies indicate parents' biases against girls' education (Uccelli 1999; Benavides 2006). Thus, although rural people have been investing in education for decades now (Ames 2002), what seems new from these data is that higher educational qualifications are desirable not only for boys, but also for girls. Girls, with their mothers' support, want to complete secondary education and pursue higher education and/or other occupations beyond agricultural or manual work.

One major reason for this change is the presence of significant social, economic and environmental changes combined with the persistent poverty in rural areas. Indeed, goals of economic improvement and escaping poverty were strong for all the Young Lives case study children, both girls and boys. Rural children and their families seemed very aware of the limited prospects for moving out of poverty without higher educational qualifications: rural poverty has not decreased as much as in cities, despite sustained economic growth in the country. In order to survive, rural households need to diversify their livelihoods and sources of income: about 50\% of rural families in Peru combine agricultural and nonagricultural income; these families are less poor than those that rely only in agriculture and 
show better living conditions (Escobal 2001). Education is necessary for income diversification as very few jobs outside agriculture are available for people without educational credentials, and those that are, are low paid. In addition to this, the effects of climate change in the highly vulnerable ecosystems of the Andes (Fraser 2010) make it extremely difficult for peasants to secure their provision of food as in the past, thus strengthening the search for diversification.

If pressing changes in the immediate context make overcoming poverty a shared goal for both girls and boys, what is distinctive about the rural and indigenous girls examined here, and their mothers, is that they have also imbued educational aspirations with the desire to overcome oppressive gender relations within the more intimate sphere of domestic relationships, which in turn impacts on the construction of female identities, the third question to address.

Education as a way to overcome oppressive gender relations was a key theme in the cases of María and Luz, where either mothers or daughters suggested that becoming a wife or a mother, the traditional female roles in their communities, was not necessarily at the centre of their future plans, and, moreover, should be avoided or delayed as much as possible. Instead, they were advocating the construction of radically different female identities, in which educational qualifications occupy a central place. Thus, education was seen as an alternative means of personal fulfilment or 'progress', which in turn may lead to autonomy and economic independence, thus reconfiguring female positions in strongly unequal and gendered social relations. Young women have grounds to conceive such projects: social changes in the wider society mean that more employment opportunities for young women are available (in the growing service sector, for example) than before. The construction of these new female identities poses several paradoxes around aspects of the existing 
identities, such as motherhood, ethnicity and rurality. The first paradox is set by the mothers: by advising their daughters not to marry and have children, these rural women are challenging their own female identities not only in terms of education and occupation but also as wives and mothers. The rejection of marriage and children comes as a rejection of persistent oppressive gender relationships in which male partners control not only key material resources but also their female partners' actions and decisions. Women therefore identify education as a way to free themselves from such control and to access material resources directly. However, this autonomy implies renunciation of other important dimensions of female identity in rural and indigenous contexts. Gender relationships in the intimate sphere of home seem so difficult to change that they are avoided, indicating the persistent problems with securing real transformations in this realm. Nevertheless, by rejecting of the aspiration to form a new family, girls and their mothers are not aiming for individualism; on the contrary, reciprocity in the form of financial support is expected from the educated girl, not only to her parents, but also to her younger siblings, who will need to study as well. Thus the young woman is still perceived as part of family networks and shared responsibilities.

The second paradox is related to ethnicity and the contradictory movement towards rejecting gendered and racial stereotypes whilst at the same time renouncing (or disguising) ethnic identities. This is most clearly exemplified by the case of Eva. Her mother certainly showed ambivalence towards the new female identity she aspires to for her daughter: although she disapproves of Eva's rejection of (and contempt for) the very markers of her ethnic identity; she ultimately understood Eva's attitude as an attempt to avoid the discrimination indigenous people experience in Peru. The education young women pursue simultaneously helps them to overcome the label of poor, ignorant, indigenous peasants, 
and denies them the possibility to inscribe ethnicity in the new educated person that emerges. Walkerdine $(2003,245)$ points out how the remaking of female identities demands at times 'a complete negation of the Other self'. Taking this approach to Eva's case, one can see that in order to remake herself as an educated young woman, as a 'somebody', she needs to negate her other indigenous, peasant and rural self, which is defined both as an ethnic and as a class position (since the 'Indian' is equated with the poor). Luz and her mother, who were both socialised in urban environments, have already lost external markers of ethnic identity, and although both retain their indigenous language, Luz is very aware she cannot use it in school without risking being derided. Thus, for indigenous women, longer educational careers require changes in their appearance, so that they lose signs of their ethnic identity, thus further distancing themselves from their mothers' female identities. However girls continue being part of their families and ethnic communities and reciprocal exchanges are expected. The tension remains however since, although changes are inevitable in intercultural encounters, some of them reveal the unequal power and prestige of the different cultures in contact. Indeed, schooling has been resisted for the very negation of the indigenous condition it requires for becoming a citizen (Ames 2002; Luykx 1996, 1999). The third and final paradox is that, if rural girls achieve the educational credentials to access non-manual work, they will move to urban centres, as rural areas have not developed positions and services to employ nonmanual workers apart from a few health and education jobs.

Thus, to overcome the various inequalities that affect their lives (persistent poverty, gender oppression, and ethnic discrimination) rural and indigenous girls pursue an educational career that could entail stopping being rural and looking indigenous, and postponing or abandoning marriage and motherhood. There are several dimensions to be renounced to in 
this model, and thus the freedom to gain is paradoxical. Once again, change and contact with other social worlds can be positive, but the changes outlined here evidence the unequal structures of Peruvian society.

The high educational aspirations of both rural girls and their mothers do not mean however that these projects are not problematic. Several factors may prevent the achievement of the desired trajectories: economic issues - not having money to study; health issues that increase pressure on young members to sustain the household; social issues - (bad) friendships leading to risky behaviours (alcohol or drug abuse); or sexual relationships and pregnancy.

In fact, some of these issues affected the young people under study: Eva started paid work to cover her own educational expenses when her father got sick back in 2008. Although she had completed secondary school, at 17 years old she was at home in 2011 (last time she was visited), working on the farm, as family resources were insufficient to pay for higher education. Eva had not abandoned her plans for further education, but postponed them until she could combine work and study. This will also probably be the case for Maria; she was in her final year of secondary school at age 16, when last visited. Luz was in a more privileged situation: At age 16 she had completed secondary school and was enrolled at a private university in her own city. Her family had more resources and can support her, although she will also combine study and work (in the family factory). The three case studies presented in more detail are no exceptions but common trends among the full set of case studies, as shown in the Appendix: all but one of the girls completed secondary school or were about to do so, as they had envisaged back in 2007. Indeed, the only exception exemplifies one of the common threats to their daughters' 
educational careers that parents feared: early pregnancy. For this reason it is worth to pause at this case, albeit briefly.

Diana lived in the same village as Maria. Her family showed a similar poverty level to María's (both households belonged to the poorest quintile of the sample), but had different family structure and background: a single mother, who had only had two years of education, with seven children. Diana walked 45 minutes every day to the neighbouring village to attend secondary school. By the second interview in 2008 she already seemed tired of doing this and showed little motivation for schooling. By 2009, when the third survey round took place, Diana had left both the school and the family home and was working and living with a boyfriend in another village. By 2011, at 16 years old, she had returned home with a new-born baby. The fact she had a baby means there is almost no prospect of her going back to school, not because of moral issues, but because she is socially considered as a woman, not as a girl any more.

Diana's trajectory is not uncommon in rural areas, especially in the Amazon region, where the age of first pregnancy is earlier than in other regions (INEI 2010a). Both in the Amazon and in the Andes, marriage and parenthood are highly valued life projects and proof of adult status. However, a delay to start such projects is becoming socially acceptable, as the individual and group interviews with adults and children alike showed in the three sites. The conventions regarding female roles thus may be undergoing a process of change and the new configurations of women's identity and practice, as stated at the beginning, are to be felt especially in the younger generation: a new and broader range of subject positions are available for indigenous and rural girls, and the pressing needs their families and communities are facing speed up the need to explore them. The narratives analysed here expose the multiple inequalities young rural and indigenous girls face because of their 
poverty, their ethnicity, their location and their gender, but remind us that critical views and actions can take place within configurations of intergenerational and shared projects, even against structural disadvantage and with little institutional support.

\section{Conclusion}

Young rural women's identities and choices are changing in important ways, creating new and desired ways of being. The perspectives of rural girls, and their mothers, analysed here are questioning the traditional subject positions available for women in rural areas and widening horizons for the younger generation. New discourses and practices that prioritise education over early marriage and motherhood are emerging, not (only) as a result of external imposition, but as a response to a changing social and economic context, where agricultural work is not enough for family survival. They are also a response to oppressive gender relationships where men still have a great deal of control over their female partners' actions and decisions. Women therefore identify education as a way to secure more autonomy and financial independence from men, rejecting at the same time the high degree of control men have over their lives.

By simply completing secondary education, the rural and indigenous girls participating in the Young Lives study have exceeded the educational level of their mothers, some by a large margin. Despite their achievements however, these rural girls still have to navigate the inequalities of the educational system: the low quality of public schools in general, but particularly of rural schools, is widely known and may prevent entrance to universities or hinder young women's ability to complete university without adequate support and mentoring. The lack of scholarship schemes make young people from poor households extremely vulnerable to any shock or unexpected event that causes their family to require 
them back to contribute to the family economy. Indeed, the same factors that menaced the completion of secondary school (i.e. limited resources, starting a family) are still at play and may interrupt these girls' educational trajectories.

Therefore, it is of key importance to understand better the change in needs and perceptions that these trajectories may be signalling in order to offer young rural women the resources and structural possibilities they and their families are actively searching for. This would imply the recognition of not only the desire to overcome poverty, but also demands for more equal ethnic and gender relations in the economic, social and educational spheres.

\section{Funding source}

Young Lives is core-funded from 2001 to 2017 by UK aid from the UK Department for International Development (DFID) and co-funded by the Netherlands Ministry of Foreign Affairs from 2010 to 2014. Sub-studies are funded by the Bernard van Leer Foundation and the Oak Foundation. The views expressed are those of the author. They are not necessarily those of, or endorsed by, Young Lives, the University of Oxford, DFID or other funders.

\section{Acknowledgements}

I wrote this paper during my time as a visiting scholar in the Department of Social and Cultural Anthropology at the Autonomous University of Barcelona in 2011. I am deeply grateful to Silvia Carrasco for her warm welcome, inspiration and support during my whole stay, to Maribel Ponferrada for her comments and to all my colleagues at the EMIGRA Research Group for creating an excellent human and professional environment.

\section{References}

Ames, P. 2002. Para ser iguales, para ser distintos: Educación, escritura y poder en el Perú. Lima: IEP. 
Ames, P. 2005.When access is not enough: the educational exclusion of rural girls in Peru. In: Beyond access: Transforming policy and practice for gender equality in education, ed. E. Unterhalter and S. Aikman, 149-65. Oxford: Oxfam.

Ames, P. 2011. Language, culture and identity in the transition to primary school: challenges to indigenous children's rights to education. International Journal of Educational Development 32: 454-462.

Benavides, M. 2006. Las escuelas, las familias y el género. In: Las brechas invisibles: hacia una equidad de género en la educación, ed. P. Ames, 233-256. Lima: UPCH-IEPUNFPA.

Connell, R., and J. Messerschmidt. 2005. Hegemonic masculinity: Rethinking the concept. Gender and Society 19: 829-59.

Crivello, G. 2009. Becoming somebody: Youth transitions through education and migration - evidence from Young Lives, Working Paper 43, Oxford: Young Lives.

Cueto, S., J. Escobal, M. Penny, and P. Ames. 2011. Tracking disparities: Who gets left behind? Initial findings from Peru. Round 3 Survey Report. Oxford: Young Lives.

Escobal, J. 2001. The determinants of nonfarm income diversification in rural Peru. World Development 29, no. 3: 497-508.

Fraser, A. 2010. The cost of climate change: Peru feels the heat of global warming. Update 118. http://www.perusupportgroup.org.uk/article.php?article id=174 (last accessed $10 / 06 / 2012)$

Holland, D., W. Lachicotte, D. Skinner, C. Cain. 1998. Identity and agency in cultural worlds. Cambridge, M.A.: Harvard University Press.

Holland, D., and B. Levinson. 1996. The cultural production of the educated person: An introduction. In The cultural production of the educated person: Critical 
ethnographies of schooling and local practice, ed. B. Levinson, D. Foley, and D. Holland, 1-54. Albany, N.Y.: SUNY Press. .

INEI. 2010a. Encuesta Nacional Demográfica y de Salud Familiar 2009 Informe principal. Lima: INEI.

INEI. 2010b. Informe Técnico. Evolución de la pobreza al 2009. Lima: INEI.

INEI. 2012. Perú en cifras. Indicadores sociales.

http://www.inei.gob.pe/perucifrasHTM/inf-

soc/cuadro.asp?cod=8193\&name=ODM11\&ext=GIF (last accessed January 19, 2012).

Leahy, T. 1994.Taking up a position: Discourses of femininity and adolescence in the context of man/girl relationships. Gender and Society 8, no.1, 48-72.

Lutrell, W. 1996. Becoming somebody in and against the school. Toward a psychocultural theory of gender and self-making. In The cultural production of the educated person: Critical ethnographies of schooling and local practice, ed. B. Levinson, D. Foley, and D. Holland, 93-118. Albany, N.Y.: SUNY Press.

Luykx, A. 1996. From indios to profesionales: Stereotypes and student resistance in Bolivian teacher training. In, The cultural production of the educated person: Critical ethnographies of schooling and local practice, ed. B. Levinson, D. Foley, and D. Holland, 239-72. Albany, N.Y.: SUNY Press.

Luykx, A. 1999. The citizen factory: Schooling and cultural production in Bolivia. Albany, N.Y.: SUNY Press.

Meyers, S. 2011. They didn't tell me anything: Women's literacy and resistance in rural Mexico. Gender and Education 23, no 7: 857-71. 
Ministerio de Trabajo - MINTRA. 2009. Informe anual. La mujer en el mercado laboral peruano: 2009. Lima: Ministerio de Trabajo.

Mirza, H.S. 2006. 'Race', gender and educational desire. Race Ethnicity and Education 9, no. 2: 137-58.

Montero, C. 2006. La exclusión educativa de las niñas del campo: ¿pasado o presente? In Las brechas invisibles: Hacia una equidad de género en la educación, ed. P. Ames, 20332. Lima: UPCH-IEP-UNFPA.

Oliart, P. 2004. ¿Para qué estudiar?: la problemática educativa de niñas y mujeres en áreas rurales del Perú. In Género, etnicidad y educación en América Latina, ed. I. Schicra, 49-60. Madrid: Morata.

Rockwell, E. 1996. Keys to Appropriation: Rural schooling in Mexico. In, The cultural production of the educated person: Critical ethnographies of schooling and local practice, ed. B. Levinson, D. Foley, and D. Holland, 301-324. Albany, N.Y.: SUNY Press. Stromquist, N. 2006. Gender, education and the possibility of transformative knowledge, Compare: A Journal of Comparative and International Education 36, no. 2: 145-61.

Uccelli, F. 1999. Familias campesinas: Educación y Democracia en el sur andino. In: El poder visto desde abajo: Democracia, educación y ciudadanía en espacios locales, ed. M. Tanaka, 187-256. Lima: IEP.

UNESCO. 2002. Gender equality in basic education in Latin America and the Caribbean. State of the art. Santiago: UNESCO

Walkerdine, V. 2003. Reclassifying upward mobility: Femininity and the neo-liberal subject, Gender and Education, 15, no. 3: 237-48.

Wexler, P. 1992. Becoming somebody: Toward a social psychology of school. London: Falmer Press. 
Winkler, D. 2004. Investigaciones sobre etnicidad, raza, género y educación en las

Américas. ed. D. Winkler and S. Cueto, Etnicidad Raza, género y educación en América

Latina. Santiago de Chile: PREAL, 1-32.

\section{Appendix}

[Contents in separate file]

\section{Notes}

${ }^{1}$ See http://www.nuevastrenzas.org/es/resultados/todos-los-resultados/98-vadesapareciendo-la-brecha-de-genero-en-educacion

${ }^{2}$ Pseudonyms are used for both sites and people, in order to protect research participants' anonymity. Villages are named after the province they belong to, while communities with more than 40,000 inhabitants are named after the district they belong to. 